\title{
Brian Friel's Translations, a Play on Power, Space, and History
}

\author{
Maryam Beyad', Mohammad Bagher Shabanpour ${ }^{2, *}$ \\ ${ }^{1,2}$ University of Tehran, Tehran, Iran \\ *Corresponding author: mb.shabanpour@ut.ac.ir
}

\begin{abstract}
Geography has received great attention since the $19^{\text {th }}$ century. Kant established it as a discipline which resulted in the development of geographical equipment. Consequently, surveying projects were launched in England. This paper argues that Friel's Translations depicts the extinction of the Irish culture, done by the Army's implementation of Ireland Ordnance Survey in 1830, in which Irish/Gaelic toponyms, carrying a great volume of a people's history, were anglicised. The English Empire strengthened its domination over Ireland through creating new maps of the Northern territories. The paper does a Foucauldian reading of geography, as a contemporary knowledge, which aided the reconstitution of the British power to hamper the contemporary revolutions or invasions. It maintains that Translations is a play on space and history, in which the role of space outweighs that of time, so does the production of a new space and the extinction of old spaces through Ordnance Survey.
\end{abstract}

Keywords: Brian Friel, Translations, Space, Geography, History, Power and Knowledge, Toponym

\section{Introduction}

Brian Friel (1929-2015) was an Irish dramatist and short story writer, known as one of the greatest contemporary dramatists writing in English. He was born in Omagh, in County Tyrone, one of the six counties of Northern Ireland. He was educated at St. Patrick's College and St. Joseph's Training College, and then went to Londonderry/Derry (there is still a dispute on the right name of the city) to teach in schools. Many a literary writer's outlooks on the world around form in the geography they breathe in. Friel's stay in this city probably influenced his later works in which he discussed the issues of land, identity, space, and place-names. He taught there for ten years, before he began writing full time in late 1950s. 
His first success in drama was Philadelphia, Here I Come! (1963), the main character of which is an Irish immigrant building up the present with his connections with his land of origin and land of immigration (Russell, 2014: p. 30). His later successes were The Freedom of the City (1973), an anti-British or anti-establishment play (Power, 1978: p. 114) set in Londonderry/Derry, Making History (1988) making the Nine Years' War its core issue, Translations (1980) a play on land, language, and struggle, and Dancing at Lughnasa (1990) in which Friel brought a family from Ballybeg on stage, one hundred years after what happened to the land and its folks in Translations. The common issue in Friel's plays is Irish history, language, and land. Translations deals with the problem of history and identity in Ireland. It also concerns different groups' confrontation in Ireland's exposition to modernity like the colonial projects of Ordnance Survey and National School. This paper argues that the play is deeply entangled with space-oriented matters including land, power, knowledge, and identity (manifested through the issues on language and placenames), making it a spatial narration. The paper falls into four parts. The first part presents a short history of space and discusses what shifts and alterations it had as a key term in human intellect. Then, the paper studies the interplay of space and history as well as the weight of space in historiography. In the third part, geography as a knowledge is discussed in respect to power, with some references to the play. The last part examines to what extent Friel's Translations is spatial.

\section{History of Space}

Questions of space, physical or mental, have always occupied human mind. The questions resulted in the Ptolemaic cosmology and the Euclidian geometry in ancient times. The Cosmos in cosmology, which is a leading principle in human knowledge, refers to the Greek kosmos meaning order, harmony, and the world, and geo in geometry, the apparatus to make the world abstract, drives from the Greek geo or ge meaning earth. Both Kosmos and Geo have spatial significance. While it does not seem necessary to explain the importance of these terms in all human knowledge, a short history of the term space will be significant. Plato's allegory of cave classifies the universe into different places, showing the postures of observers towards the physical and metaphysical worlds just as, in his Timaeus, he puts things into three categories; each has its specific spaces (Huggett, 1999: p.4). The first category includes what Tiamaeus names 'proper object of intellect' (Plato, 2009: p. 45). Plato explains that they are 'the class of things... which neither admit anything else into themselves from elsewhere nor enter anything else themselves, and which are imperceptible' (2009: p. 44); the second class are similar to the first class but they 'are perceptible, created, and in perpetual motion since they come into existence in 
a particular place' (p. 45); and the last category of being 'is space, which exists for ever and is indestructible, and which acts as the arena for everything that is subject to creation' (p.45). Later, he delineates space as a container occupied by objects (Huggett, 1999: p. 4) as Timaeus holds, "every existing thing must surely exist in some particular place and must occupy some space" (Plato, 2009: p.45). Following Plato, Aristotle also defined space as a container in which a body positions. The definition of space as a container prevailed human knowledge until late modern and postmodern times.

The Medieval Age employed the Aristotelian concept of space. However, Foucault (1980) argues in The Order of Things that objects, in medieval times, were categorised in a closed network of spaces belonging to a hierarchy (1980: p. 61). The whole world was regarded as a place in which objects were categorised based on their resemblance to each other, as it is described in Translations that before the establishment of National Schools in Ireland, people had been learning Gaelic, Greek, Latin, and some English in a state of agreement since all languages might have been deeded similar, as Irish Hugh told Captain Lancey of Royal Engineers that 'our own culture and the classical tongues made a happier conjugations' (Friel, 1981: p. 25).

At the outset of seventeenth century, the former dominant system of thinking and signs crashed. Put it in Foucauldian language, it was a moment of a discontinuity. Foucault (1980) describes it 'the chimeras of similitude loom up on all sides, but they are recognized as chimeras' (p.57). He maintains that both Descartes and Bacon had showed the inability of the method of resemblance to build knowledge anymore (Gutting, 2005: p. 146). Foucault (1980) calls this a new era, labeled Classical Age, as 'rationalism' (p. 60). It can be concluded that in the course of this discursive shift, the definition of space remained intact, but the standards for categorization within the container, space, changed drastically.

The nineteenth century was the ascendency of time over space. In an interview with the editor of the journal Herodote, Questions on Geography, Foucault (1980) notifies the 'devaluation of space prevailing for generation' (p.194). In the last scene of the play, when the Anglicisation of Gaelic toponyms is nearly done, Hugh's defensive chauvinistic sentiment and xenophobic posture transforms into cultural assimilation. The interesting point here is that Hugh, rising against the 19th century superiority of time over space, spatializes his new stance towards language and identity, as he says 'We must learn where we live. We must learn to make them our own. We must make them our new home" (Friel, 1981: p. 66).Moreover, rightly expressed by some scholars like David Harvey, the capitalist ethics of accumulation of wealth and creation of surplus value during and after the Industrial Revolution, made time 
chartered and quantified so that proficiency and labor (which can be calculated in temporal unit) were of great moment. However, this phenomenon is rooted in human language, as Tuan (1979) states, which 'is far better suited to the narration of events than to the depiction of scenes' (p.391). Literary critics can also claim that the second half of nineteenth century was the age of novel with its emphasis on plot, temporality, history, evolution, fate etc.; nevertheless, this genre later acted as a double-edged sword in modern and postmodern fiction. Also, scholars like Yi-Fu Tuan argue that nature has provided man with tools to calculate time, e.g. sunrise, sunset, but did not probably give man any tools for measurement of space (Tuan, 1979: 391); however, it must be noted that the importance of time in the second half of nineteenth century was much more than the importance which nature puts in human life. Foucault (1980) states that 'space was treated as the dead, the fixed, the undialectical, and the immobile. Time, on the contrary, was richness, fecundity, life, dialectic' (p.70). Although the Ordnance Project of surveying North Ireland in the nineteenth century seems contradictory to what Foucault says, it must be noted that Ireland, as a physical space, was surveyed, being turned into abstract space in form of precise maps to help create efficiency i.e. time-saving labor consumption in military as well as colonial pursuits.

\section{Space and History}

The concept of being is strongly related to the notion of space since any object is perceptible generally as an entity only if it occupies a space; that is why vacuum is commonly associated with the idea of nothing or not being. A great part of man's identity is formed by the space of living, owing to the fact that concepts like name, nationality, blood, and language are space-oriented though man has always been less conscious of space, albeit not the moment a person loses it, as Owen, formerly thinking that toponyms are just unimportant names, after he helped to anglicize the names, suddenly becomes aware of the loss: 'OWEN finds a sack and throws it across his shoulders.) OWEN: I know where I live' (Friel, 1981: p. 66). The mysterious nature of time, throughout history, has distracted historians to take enough consideration of space. Most history books, chronicles, annals, and diaries were written in terms of time rather than space. This does not mean that space was removed from the history books but it was not in the foreground; however, in all histories a spatial aspect provides the backdrop for time to take on the mantle. Therefore, it can be concluded that history focused on both time and place, while place was always neglected as the secondary element in historiography. Michelet's the History of France is the best example in which he described the nineteenth century France 'including a spatial dimension in his model' (Hutton, 1976: p.247) 
since he believed that 'man's quest for liberty proceeds in space as well as time' (Hutton, 1976: p.247). That is why, it can be speculated, history abounds with the heroic live of warriors who took up arms for lands and boundaries.

Despite the relative neglect of place as a key factor in historiography, it is not much neglected in language. There are a large number of words roughly signifying spatiality, for instance, space, place, land, terrain, soil, location, position, area, region, words derived from root words geo and topo, etc. This brings about a 'conceptual primacy' (Regier, 1996: p. 31) of space in language. The interconnection of language and spatiality, a concept formed in language, Reiger (1996) holds, is thanks to 'its expression through closed-class terms [against open-class terms] and... its pervasive influence as a metaphorical structuring device for non-spatial domains' (p. 31), as interestingly at the end of act two, Yolland and Maire get physically and emotionally closer to each other by Yolland's recitation of Gaelic toponyms, through which he probably succeeded in expressing his strong affection for her:

YOLLAND: Maire.

YOLLAND: Maire Chatach.

YOLLAND: Bun na hAbhann?.... Druim Dubh? .... Lis na nGrall.

MAIRE: Lis na nGadh.

MAIRE: Carraig an Phoill.

YOLLAND: Carraig na Ri. Loch na nEan.

MAIRE: Loch an Iubhair. Machaire Buidhe.

YOLLAND: Machaire Mor. Cnoc na Mona.

MAIRE: Cnoa na nGanhar.

YOLLAND: Mulllach

MAIRE: Port.

YOLLAND: Tor.

MAIRE: Lag.

YOLLAND: I wish to God you could understand me" (Friel, 1981, 51-52). 
Geography had been mostly descriptive and more like travelogues. It was one of the old and main sources of knowledge for human. Through history it has had different forms and absorbed different volumes of attention from the ancient Greece which most of 'the European tradition of geographical learning is traced' (Dikshit, 1997: p. ix) to the Arab's breakthrough's in geography during the middle ages 'when geographical learning in Europe had suffered complete eclipse owing to the stranglehold of theocracy' (Dikshit, 1997: p. ix) to the Renaissance's great investment of knowledge and money in exploration 'when the greatly expanded horizon of geographical knowledge about lands and peoples across the globe stimulated a renewed spirit of inquiry about man's relationship with nature' (Dikshit, 1997: p. ix), which is evoked by Yolland's love for Irish land and woman, Maire,: 'YOLLAND: Yes-yes? Go on-go on-say anything at all-I love the sound of your speech' (Friel, 1981: p. 50).

In his article 'Spatial Criticism: Critical Geography, Space, Place and Textuality', Phillip Wegner reviews the latest theories on space and its interrelations with language and culture. Wegner (2015) maintains western modernity was both a historical and a graphical-spatial project, i.e. space is both a product and a force; it is influenced and it influences (p. 180). The theory of the production of space is notable since it brings into focus the effects of a state's manipulation of space and interactions among cultures and identities. Moreover, language itself, through which space is created, is an actor in space, as Owen says 'we name a thing and-bang!-it leaps into existence!' (Friel, 1981: p.45), showing how, through language, a spatial entity can be created and consequently create new spatiality. Henri Lefebvre in his The Production of Space rejects Cartesian definitions of place and notifies that place is not preexisting void being to be filled. He asserts that social place subsumes thing produced. Foucault also devised a novel theory of historiography and refuted the traditional style of writing history. He analyzed the shifts from one discourse to another and the consequential change of social space, developing innovative methodologies, i.e. archaeology and genealogy. In his histories of disciplines, Foucault documented discursive changes in the western mind reflecting on the contemporaneous spatial changes in the western mentality, e.g. in his writings on heterotopia and Bentham's Panopticon. Friel shows the discursive shift from premodernity to modernity, which is contextualized in place-names and language, throughout the play, for example in the beginning of the play, through Maire's making comparison between her Latin, sign of pre-modernity, and her English, sign of modernity, as she says, 'That's the height of my Latin. Fit me better if I had even that much English' (Friel, 1981: p.15), and later says, 'the old language is a barrier to modern progress... I don't want Greek. I don't want Latin. I want English' (Friel, 1981: p. 25), or as Yolland indicates to his father's life that 'Ancient time was at end. 
The world had cast off its old skin' (Friel, 1981: p. 40), and to his own life 'of experience being of a totally different order' (Friel, 1981: p.15).

\section{Geography and Power}

Tuan (1979) argues 'place defines the nature of geography' (p. 387) so geography studies space as its focal subject. Hence, the volume of consideration to the concept of space or the emphasis on the primacy of place over time in non-geographical disciplines can be a yardstick for measuring the value of geography in humanities. Geographical studies involve the spatial and temporal distribution of phenomena, physical features, and the interaction of humans and their environment.

Geographical surveys in Europe had always been overloaded with religion and Eurocentrism. After the establishment of geography as a science, while it is justifiable to expect impartiality in later geographies, they remained skewed in a much more subtle manner. Geographical descriptions of before $19^{\text {th }}$ century were based not only on some calculated mathematical principles but also on some economic and political systems of ideas so that the dominance of Europe on other parts of the world, say, discovered lands, would be preserved.

Some scholars argue that Kant regarded geography as one of the main bases of his philosophical speculations (Dikshit, 1997: p. 38). His emphasis on geography paved the way for geographers to lay the foundations of placing geography in sciences; and consequently, among other scientific fields of study in European universities (Dikshit, 1997: p.36). The significance of Kant's positive impact on geography(regarded positive in Enlightenment-is recognized when the states of geography is compared with each other before and after Kant's lectures on geography from 1756 to 1796 . The maturation of geography as an academic discipline started at this point. The upshot of Kant's years of teaching geography in university was that geography was employed as a science in practice, especially in Orientalism as well as in area studies and in later decades of the twentieth century was Alexander Von Humboldt launched, for the first time, the institutionalization of empiricism in geography, advocating scientific research as the basis of geographical studies (Dikshit, 1997: p. 42). Michael Church (2011) illustrates that Humboldt's geography was established upon three principles:

'(1) That measurements are of paramount importance, and that measurements must be made of many qualities of the environment as possible; but (2) that an holistic and aesthetic sensibility must be present in one's summary appreciation of and report on landscape; and (3) that 
geography is strictly about the compilation and synthesis of the present facts of the landscape - it is neither a historical nor causally interpretive science' (p.29).

According to the first principles, scientific measurement got the utmost importance in the $19^{\text {th }}$ century. Doalty tells his friends about the presence of 'Red Coats' (Friel, 1981: p.17) who were working with 'chains and peeping through that big machine they lug about everywhere with them' (Friel, 1981: p.17). This big machine is a theodolite, Ramsden Theodolite, constructed to be used for Ordnance Survey (Owen \& Pilbeam, 1992: p.3). Jesse Ramsden's Theodolite was the most precise generation of theodolites in the Isles because it 'was capable of observing more than seventy miles with no more than two seconds of arc error' (Owen and Pilbeam, 1992: p.7). English government's using Ramsden Theodolite points to Foucault's theory of knowledge and power. This will be discussed more.

Based on Humboldt's first principle, following the shift in nature of approaches to geography and its becoming a field of study in European universities, European government, especially the British Empire, started to undertake the changes. New attempts commenced to make new maps of territories with high accuracy. Seymour (1980) in his book A History of the Ordnance Survey quotes from Thomas Burnet's The Sacred Theory of the Earth (1681):

'every prince should have... a draught of his country of dominions, to see how the ground lies in the several parts of them,... Such a map or survey would be useful both in time of war and peace, and many good observations might be made by it, not only as to natural history and philosophy, but also in order to the perfect improvement of a country' (p. 1) [emphasis mine].

This shows that mapmaking was among top priorities of British Empire to utilise his dominions at most. It was, in reality, a must for the British Empire to reconstitute its measurements of colonies in the closing years of $18^{\text {th }}$ Century (Seymour, 1980: p. 1); therefore, 'Captain Lancey of the Royal engineers' (Friel, 1981: p. 24) was introduced as the chief to be 'engaged in the Ordnance Survey of the area' (Friel, 1981: p. 24). In fact, all regions in Britain and English colonies had been, more or less, surveyed but they were not accurate enough, as Owen says: "we're making a six-inch map of the country (Friel, 1981: p. 43), to be used for military purposes. Ordnance Survey was going to make maps suiting military purposes" (Owen and Pilbeam, 1992: p. 3).

Surveying Northern Ireland started after the establishment of Ordnance Survey, and become fully fledged in early 1830s (Seymour, 1980: p. 87). The Ordnance Survey 
was established in 1824 which was part of British Empires increase of control over its colonies (Jackson, 2994: p. 126) Thus, Ordnance survey was implemented in other colonies, e.g., 'the Great Trigonometrical Survey in India (in 1818) and the Geological Survey of India (in 1851)' (Jackson, 2994: p. 126) [parentheses mine].

The Royal ascendancy over the Isles was jeopardised by the consequential context at the time affected by the Prussian will to power, the American Revolution in 17751783, French Revolution in 1789-1799, the threat of Irish dissidents, and land reevaluation to levy more tax. Lancey proclaims:

'His Majesty's government has ordered the first ever comprehensive survey of this entire country - a general triangulation which will embrace detailed hydrographic and topographic information and which will be executed to a scale of six inches to the English mile.

...so that the military authorities will be equipped with up-to-date and accurate information on every corner of this part of the Empire

...the entire basis of land evaluation can be reassessed for purposes of more equitable taxation.

...I wish to quote two brief extracts from the white paper which is our governing charter: '...the present survey has for its objects the relief which can be afforded to the proprietors and occupiers of land from unequal taxation.'

... 'So this survey cannot but be received as proof of the disposition of this government to advance the interests of Ireland.' My sentiments, too' (Friel, 1981: p. 31).

The government used the trailblazing innovations and sophisticated equipment of the time with the intentions listed by Seymour (1980) from Thomas Burnet's The Sacred Theory of the Earth (1681). It is deduced that the main purpose, was to make the government immune of potential uprisings in the Northern region with respect to the experience of American Revolution in 1770s, the 1798 rebellion inspired by the American Revolution (Bartlett, 2004: p. 81), and later on the reverberations of the French Revolution. According to the official website of Ordnance Survey, after the French revolution shook France in 1987, the British Empire, in fear of an invasion, founded Ordnance Survey in 1791. It felt the need to make a comprehensive and accurate map of the South Coast England. It authorized the defense ministry of the day, Board of Ordnance, to shoulder the survey task. Later, the need to survey the whole Isles arose. While Owen thought there seemed to be no problem with the 
project, as he says 'is there something sinister in that?' (Friel, 1981: p. 43), Manus thinks that 'there was nothing uncertain about what Lancey said: It's a bloody military operation! (Friel, 1981: p. 32)

The project aimed to provide the army with more accurate maps in case of France's invasion, re-evaluate the land for more taxation, and less conflicts between owners and the government, and the as Seymour's quotation from Burnet indicates, provide considerable and precious information about natural history and philosophy. All in all, based on Foucault's notion of power and knowledge, the dominant discourse moved to reconstitute the power relations and stabilize its dominance. The theory states that power is succored by knowledge to reconstitute itself and that power's reconstitution of itself brings about more knowledge. In this case the latest technology of the time helped the power strengthen itself against the potential invasions, and on the other hand, the dominant power through the implementation of the Ordnance Survey added to the volume of natural and geographical knowledge about Ireland.

Moreover, based on Humboldt's third principle, space as the case study of geography was of greater importance than time. Does 'the present facts of the landscape' (Church, 2011: p. 29) means washing off the historical facts of the landscapes? If yes, new maps show the accurate location of a place, a fact, but not necessarily the historical significance of the place (concentrated in its name). Can this principle hypothetically result in a cultural genocide? This is a really controversial question as at the end of the day although the play shows the incipient extinction of Gaelic, the culture is tried to be saved, by Friel, and his speaker inside the play Hugh, as he says that Gaelic 'is a rich language... full of the mythologies of fantasy and hope and selfdeception - a syntax opulent with tomorrows. It is our response to mud cabins and a diet of potatoes; our only method of replying to... inevitabilities' (Friel, 1981: p. 42), so now that the language itself is being wiped out?! Hugh responds, 'words are signals, counters. They are not immortal. And it can happen-to use an image you'll understand-it can happen that a civilization can be imprisoned in a linguistic contour which no longer matches the landscape of... fact' (Friel, 1981: p. 43), implying the assimilation of English and make it imbued with Gaelic images.

Principally, toponyms signify the topographical features of places which is also closely associated with the local culture: 'Individuals perceive spatial and mental places described by toponyms differently' (Guyot \& Seethal, 2007: p. 2). Names of flats, plains, fields, mountain, rivers, streets, villages, cities, and neighborhoods denote or used to denote the geographical or demographical features of the location. Besides, place-names, whether made arbitrarily or by reason, are regarded as cultural repositories of a nation. Each toponym provides a great volume of information on 
the oral, unofficial, or people's history of a land. Jordan (2009) emphasizes that 'place names inform on cultural history and language of a place' (p. 2). They make an environment, a land, or a soil part of the identity of the people who reside in that land. They pass the feeling of nationhood to generation after generation. When people encountering place-names, 'not only recalling their factual concept of the place... their memories of the place... but also memories of persons and events they are associating with it... activates their emotional ties' (Jordan, 2009: p. 6), as Hugh asserts at the end of the play that 'it is not the literal past, the 'facts' of history, that shape us, but images of the past embodied in language' (Friel, 1981: p. 66).

Moreover, maps cease to function efficiently without toponyms; how can Geography, especially human geography, stop ending in absurdity with no accent on toponyms. Basically, they are used to make distinctions among places and set physical and mental borders between places, as Guyot and Seethal argue that 'place naming is, from a geographic point of view, a territorialisation process that contributes to the identity of particular places, at different scales' (Friel, 1981: p. 2). Interestingly, there were no exact borders in pre-modern time; countries were demarcated by toponyms, especially names of frontiers. This adds to its significance in many fields from politics to biology. They elucidate 'many branches of scientific, historical, and archaeological research' (Taylor \& Palmer, 1968: p. 6), interconnected to different fields of studies, including geography, etymology, history, politics, and cultural studies. So how can it be consequential to change toponyms? Does it mean a change in a people's history or language, its feeling of territory, or its nationhood?

In Translations, Friel depiction of the Anglicisation of the local toponyms in Ireland Ordnance Survey corresponds exactly to Humboldt's 'the present facts of the landscape' (Church, 2011: p. 29). Yolland says 'something is being eroded' (Friel, 1981, 43). It brings about a cut; the old generation is not able any more to pass its heritage to the young. Owen, talking to Yolland, recounts the story behind the name of a crossroad, "I know the story because my grandfather told it to me" (Friel, 1981, 44). The team of translators in the play consists of Yolland, an English orthographer, and Owen, an Irish interpreter who migrated to England, but well-informed of the regional place-names and the stories behind them. They used the etymological information of the toponyms and then get what they needed to find or coin an English equivalent, for instance, for 'Bun na hAbhann' (Friel, 1981, p.35):

OWEN: ... Bun is the Irish word for bottom. And Abha means river. So it's literally the mouth of the river. 
OWEN: ... I suppose we could Anglicise it to Bunowen; but somehow that's neither fish nor flesh.

YOLLAND: We are trying to denominate and at the same time describe that tiny area of soggy, rocky, sandy ground where that little stream enters the sea! An area known locally as Bun na hAbhann.... Burnfoot! What about Burnfoot?

YOLLAND: (Indifferently) Good, Roland. Burnfoot's good (Friel, 1981, p.35).

By means of etymological information 'Bun na hAbhann' and its pronunciation, changes into Burnfoot in English. The English equivalent is not any identical to the original version. Friel shows that 'the facts of the landscape' (Church, 2011: p. 29) can result in the fact of the person'. The Royal soldiers call Owen Roland wrongly:

MANUS: And they call you Roland! They both call You Rolland!

OWEN: Shhhhhh. Isn't it ridiculous? They seemed to get it wrong from the beginning-or else they can't pronounce Owen" (Friel, 1981, p.33).

However, Owen believes it is not much important what to be called. Changing names makes nothing change:

OWEN: Easy, man, easy. Owen-Roland-what the hell. It's only a name. It's the same me, isn't it? Well, isn't it? (Friel, 1981, p.33)

After a while, Owen finds that he lacks something:

OWEN: George! For God' sake! My name is not Roland!

YOLLAND: What?

OWEN: My name is Owen.

YOLLAND: Not Rolland?

OWEN: Owen" (Friel, 1981, p.44).

But English soldiers do not care:

OWEN: O-w-e-n.

YOLLAND: What'll we write- 
OWEN: -in the Name-Book?!

YOLLAND: R-o-w-e-n!

OWEN: Or what about Ol

YOLLAND: Ol- what?

OWEN: Oland!” (Friel, 1981, p.45)

The way they change Owen to Oland is identical to the way Owen and Yolland anglicise the place-names; the outcome is an absurd name.

The second and third of the Humboldt's principles are totally aligned. As 'the present facts of the landscape' (Church, 2011: p. 29) is worthy of significance, the landscape must be observed aesthetically as a whole in a geographical report. The aesthetical aspect of the translation team in Translations led into idiocy. While it seems a complicated process of etymological analysis and word-creating, the Anglicisation is done in an absurd manner. It is ironic that the topo of the toponym is observed with great accuracy, according to the first principle, while the nym of the toponym is observed holistically. Friel tried to echo the consequences of holistically looking at the landscapes for the Irish people, language, and culture; however, he depicts just the impetus of the change not the outcome. The catastrophic result of Anglicizing Irish toponyms is indicated by Yolland, the English engineer who is in love with both the Irish girl and Irish landscape in a paradoxical manner: 'something is being eroded' (Friel, 1981, 43). The erosion brings about a severance between the old and new generations which could not be alleviated considerably later through the Gaelic revival. Owen, the Irish assistant to Yolland, tells him the story behind the name of a crossroad: 'I know the story because my grandfather told it to me' (Friel, $1981,44)$. Now that there is none of those Gaelic toponyms, there will be no story to be (re)told by grandfathers, especially when English, which was spoken 'by a few... on occasion... for the purpose of commerce' (Friel, 1981: p. 25), is now becoming the everyday language of the students going to national schools as the school curriculum are taught in English. In fact, the Ordnance Survey, as a hard power apparatus, and national schools a soft power apparatus created a new space for Irish subject to be normalized in terms of the new Imperial discursive rules, as Own admits that 'we're standardising those names as accurately and sensitively as we can" (Friel, 1981: p. 43). 


\section{Translations; a Play on Space and History}

Drama, like any human activity, is generally historical since the story, actors, and characters are part of the contemporary history or indicate the past or current events. Yet history plays are those stage real historical figures or events. The tradition of history play in English literature dates back to its rapid development in Elizabethan time. Shakespeare and Marlowe's interest in history was rooted in the Renaissance English nationalism. Although they critiqued the Tudor power, bringing real historical figures onto the stage, they, as the spoiled children of the Virgin Queen, supported their contemporary secular-religious type of nationalism (the queen as head of the Anglican Church and the heart of nation).

Friel's plays, especially, Translations, not only include many Irish historical events, but some of them, say Translations and Making History, put historical players on stage under public investigation. Translations pivots on the project of Ordnance Survey and the establishment of National School. The project of Ordnance Survey is fully discussed so far. About hedge schools, it must be said that under the Penal Laws in the $18^{\text {th }}$ century, Catholic schools were forbidden to hold any classes; therefore, classes were held secretly, especially in rural areas, in barns. This continued in $19^{\text {th }}$ century. Set in late August 1833, Translations is in barn: 'a hedge school in the town land of Baile Beag' (Friel, 1981, p.10). These secret schools were known as hedge schools. After Mercantilism flourished in $17^{\text {th }}$ century, Irish peasants felt the need to educate. Latin, English, and Math were in the curriculum, taught by the local educated. After the foundation of National Schools in 1830s, the number of hedge-schools declined, but remained in remote areas for the catholic underprivileged.

Friel's choosing Ordnance Survey and the establishment of National School as the main subjects is of great significance owing to the Foucault's advice that the intellectual must (re)write history rather than merely read others' writings. Friel's reading of the history does not ignore temporality but spatiality is his prime concern. The first stage direction in the play reveals the writer's preoccupation with placenames as he explains that the setting is located 'in the town land of Baile Beag or Ballybeg, an Irish-speaking community in County Donegal' (Friel, 1981; p.10); later in the play, this is mentioned by Yolland: 'The day I arrived in Ballybeg-no, Baile Beag...' (Friel, 1981: p.40). The examples are many. He could not resolve his dilemma over Baile Beag or Ballybeg. County Donegal is located on the Border Region in the Province of Ulster. Friel opted for standing on the border, rather than choosing one of them. $\mathrm{He}$, in fact, looks Ireland as a single unit. 
In the initiative to rewrite history, the intellectual emphasizes the threshold, the moment of disruptions, in history. In Translations, Friel's shows the disruption of the traditional geographical discourse. The Ordnance Survey, as a discursive phenomenon, was the manifestation of the Enlightenment in the Imperial army. In order to inquire into a discipline and (re)write history, Foucault believes, intellectuals must stand beyond the discipline. Friel, in Translations, tries to stand aside so as to offer his own analysis of some specific historical events. In Foucauldian archaeological analysis, a group of elements are packed to make a totality. In Translations, Friel shows that the Ordnance survey, the establishment of National School, and the Anglicisation of toponyms are carried out to form a totality in specific period of history- notwithstanding, these historical events did not take place exactly at the same time. For example, the Irish Potato Famine occurred between 1840s, costing Ireland one million lives and the emigration of 1.5 million to North America. Interestingly, the Famine is referred in the play before 1830s. Maire says, "sweet God, did the potatoes ever fail in Baile Beag? Well, did they ever-ever? Never! There was never blight here. But we are always sniffing about for it, aren't we?" (Friel, 1981, 21) The Anachronism is not a matter inaccuracy in archaeology for the sake of finding totality in the discourse. Friel did not record some historical event but to juxtapose some events to make a totality so as to write the history of England and Ireland in early nineteenth century. This was also practiced by Edward Said in Orientalism in which he used historical events anachronistically to argue the West's mindset of the Orient showing no change.

Moreover, the use of anachronism in this play disentangles the lines of causality which is the bedrock of the established historiography. Disrupting the temporal logic of events increases the importance of spatiality of the events and also the gravity of non-temporal phenomena. Among the most principal objectives of an archaeological analysis is to ignore the temporal relations of events in history and to describe the role of science in configuration a dominant discourse. In Translations, the engineers use the geographical breakthroughs of the time, Theodolite, to make more accurate maps of Ireland. This becomes significant in Foucault's theory of knowledge and power. It becomes more significant if space is added to the knowledge and power; Knowledge helps power to create space. Maps help the Imperial Army to create new spaces. The new space was made by means of optimized Theodolite on maps, a new abstract space, and through Anglicisation of the toponyms, making new mental or cultural space. Also, new physical space was created through the dialectics between knowledge and power; all these spaces create new knowledge which helps (re)constitute power; therefore, the new structured power relations create new spaces. 
Furthermore, Foucault believes there is resistance where there is power. The tension between the locals and the English soldiers starts after the arrival of Royal military engineers; in Act I, characters are already involved in the Royal military measures. When Maire comes in the barn, she informs her fellows of the Royal soldiers' presence in the regional plains. Then, Doalty comes in and says, "brandishing a surveyor's pole" (Friel, 1981, 17). These poles were used to mark a point in land for the purpose of measurement. So, pulling out these poles or replacing them would definitely make problems for the surveyors.

'DOALTY: ...every time they'd stick one of these poles into the ground and move across the bog, I'd creep up and shift it twenty or thirty paces to the side... then they'd come back and stare at it again and scratch their heads. And Cripes, d'you know what they ended up doing? They took the bloody machine apart!' (Friel, 1981, pp.17-18)

As an act of resistance, Friel puts it here in a witty ironic way, the locals responded the British Army's intrusion by displacing the poles although Captain Lancey had lectured them, especially Hugh on the consequences of troublemaking. Friel's play is not merely a history about the dominance of a colonial power but an account of the process in which obduracy is answered by mockery.

\section{Conclusion}

The play gives a brief historical account of space, explains its significance in history and geography, and elaborates on how a Project of Surveying can changed spaces consequentially. It also argues that geography was always used by power to enlarge its dominance. English colonialism has utilised geographical and cartographical advances to explore new lands and sources of wealth. According to Foucault, knowledge is the beloved brother of power. Kant's contribution in last years of the $18^{\text {th }}$ century made geography to be established as a discipline in European universities. It was also received great attentions by the colonial power at the outset of the $19^{\text {th }}$ century. Optimisation of Theodolite in the $19^{\text {th }}$ century helped the Royal army to launch very accurate survey of the Isles, especially in Ireland. The Ireland Ordnance Survey and its impact on Gaelic culture, especially Irish toponyms, are the pivots of actions in Translations. The paper maintained that Friel's play depicts the British Empire's conducting Ireland Ordnance Survey to prevent any invasion from France and revolutionary measures by the Irish dissidents. The contributions that power and knowledge made to each other are hugely manifested in the play. It analyzed the indication of surveying machine and technology in Ordnance Survey via Foucault's theory power and knowledge. In general, in Translations, geography 
as a science is introduced as an area of knowledge which helped the British government to augment its dominance in Ireland and wipe out the Irish Culture to consolidate the position of English power in the Isles.

\section{References}

Bartlett, Thomas. (2004) Ireland, Empire, and Union, 1690-1801. In: Kenny, K (ed.), Ireland and the British Empire. Oxford: Oxford University Press, pp. 61-89

Dikshit, R. (1997) Geographical Thought: A Contextual History of Ideas. New Delhi: Prentice-Hall of India.

Church, Michael (2011). Immanuel Kant and the Emergence of Modern Geography. In: Elden, S. \& Mendieta, E. (ed.) Reading Kant's Geography. Albany: State University of New York Press, pp. 19-46.

Friel, B. (1981) Translations. London: Faber \& Faber.

Foucault, M., \& Gordon, C. (1980). Power/knowledge: Selected interviews and other writings, 1972-1977. New York: Pantheon Books.

Gutting, Gary. (2005) Foucault: A Very Short Introduction. Oxford, UK: Oxford University Press.

Guyot, S., and Seethal, C. (2007). Identity of Place, Places of Identities: Change of Place Names in Post-Apartheid South Africa. South African Geographical Journal. 89 (1), 55-63. Available from: doi: 10.1080/03736245.2007.9713873

Huggett, N. (1999) Space from Zeno to Einstein classic readings with a contemporary commentary. Cambridge, Mass.: MIT Press.

Hutton, Patrick H. (1976) Vico's Theory of History and the French Revolutionary Tradition. Journal of the History of Ideas. 37 (2), 241-256.

Jackson, Alvin. (2004) Ireland, the Union, and the Empire, 1800-1960. In: Kevin Kenny (ed.) Ireland and the British Empire. Oxford: Oxford University Press, pp. 123-153.

Jordan, P. (2009) Some Considerations on the Function of Place Names on Maps. In Proceedings of the 24th international cartographic conference, Santiago, Chile (ICC 2009): 15-21.

Owen, T., and Pilbeam, E. (1992) Ordnance Survey: Map makers to Britain since 1791. Southampton: Ordnance Survey.

Plato. (2009) Timaeus and Critias. Oxford: Oxford University Press.

Power, Victor. (1974) The Freedom of the City_by Brian Friel. Educational Theatre Journal, 26 (1) $1,113-114$.

Regier, Terry. (1996) The Human Semantic Potential: Spatial Language and Constrained Connectionism. Cambridge, MA: The MIT Press.

Russell, R. (2014) Modernity, Community, and Place in Brian Friel's Drama. Syracuse: Syracuse University Press.

Seymour, W. (1980) A History of the Ordnance Survey. Kent: Dawson.

Taylor, I., and Palmer, A. (1968) Words and places; or, Etymological illustrations of history, ethnology, and geography. Detroit: Gale Research.

Tuan, Yi-Fu. (1979). Space and Place: Humanistic Perspective. In: Gale, S. (ed.) Philosophy in geography. Dordrecht: D. Reidel Publishing Company, 387-427.

Wegner, Phillip E. (2015) Spatial criticism: Critical geography, space, place and textuality. In Wolfreys, Julian (ed.) Introducing criticism at the 21st century. Edinburgh: Edinburgh University Press, 179-201. 